\title{
REKRISTALISASI NATRIUM KLORIDA DARI LARUTAN NATRIUM KLORIDA DALAM BEBERAPA MINYAK YANG DIPANASKAN
}

\author{
WulAN SUMARNI $^{1}$, Dede SUHENDAR ${ }^{1 *}$, DAN Eko PRABOWO HADISANTOSO ${ }^{1}$ \\ ${ }^{1}$ Jurusan Kimia, Fakultas Sains dan Teknologi, UIN Sunan Gunung Djati Bandung, \\ Jalan A. H. Nasution No. 105 Cibiru Kota Bandung \\ *alamat email korespondensi: dede.suhendar@uinsgd.ac.id
}

\begin{abstract}
Informasi Artikel
Abstrak/Abstract

Riwayat Naskah :

Diterima pada 24

November 2017

Diterima setelah

direvisi pada 28

Desember 2017

Diterbitkan pada 29

Desember 2017

Garam dapur $(\mathrm{NaCl})$ merupakan kebutuhan yang sangat penting bagi manusia, diantaranya sebagai bumbu dan pengawet makanan. Konsumsi rata-rata natrium global diperkirakan 3,9 $\mathrm{g} /$ hari (setara dengan $10 \mathrm{~g} /$ hari garam) yang melebihi asupan maksimum yang disarankan yaitu 2 g/hari natrium atau setara dengan 5 g/hari garam. Selama ini kebanyakan orang mengkonsumsi makanan hanya memikirkan selera dan rasanya saja sehingga kurang memperhatikan apa yang dibutuhkan oleh tubuh. Kristal garam yang sebagian terlarut dalam mulut ditelan tanpa memberikan rasa asin. Untuk meningkatkan rasa asin dan menghindari partikel garam tertelan sebelum terlarut dalam mulut maka tingkat kelarutan kristal garam harus ditingkatkan. Mengoptimalkan bentuk fisik garam dapat dilakukan untuk mengurangi kandungan garam tanpa mengurangi kualitas yang dirasakan dalam makanan. Kristal garam

Kata Kunci: garam dengan ukuran kecil (mikrokristal) diperoleh dengan cara rekristalisasi garam dari larutannya dapur; kristal; kristalisasi; mikrokristal; $\mathrm{NaCl}$ dengan menggunakan minyak hewani dan minyak nabati sebagai medium rekristalisasinya. Hasil kristalisasi menggunakan minyak ini berhasil membuat kristal dengan ukuran mikro dan kadar air sesuai garam SNI.

Keywords: salt; crystal;

Salt ( $\mathrm{NaCl})$ is a crucial need for human being including as seasoning and food preservative. In crystallization; microcrystal; $\mathrm{NaCl}$ 2010 the global mean sodium consumption was estimated in 3.9 g/day (equivalent to approximately $10 \mathrm{~g} /$ day of salt) which exceeded the maximum recommended intake of $2 \mathrm{~g} / \mathrm{day}$ of sodium, equivalent to $5 \mathrm{~g} /$ day of salt. All this time, most people will consume food by desire and what does is taste only so that is less attention to body needs. Salt crystals that are partly dissolved are swallowed without giving saltiness. Improving saltiness perception while avoiding that salt particles be swallowed before they are dissolved in the mouth, requires that the dissolution rate of salt crystals be increased. Optimizing the physical form of salt can be for reduce the salt content without decreasing the perceived quality of foods. Small salt crystals obtained by recrystallizing the salt from the solution by using animal oil and vegetable oil as its crystallization medium. The result of crystalization using this oil succeeded in making crystal with micro size and water content according to SNI salt.
\end{abstract}

\section{PENDAHULUAN}

Natrium klorida $(\mathrm{NaCl})$ yang dikenal sebagai garam dapur merupakan kebutuhan yang sangat penting bagi masyarakat Indonesia, yaitu sebagai bumbu dan pengawet makanan. Garam menyediakan sekitar $90 \%$ dari natrium dalam makanan [1]. Pada tahun 2010 rata-rata konsumsi natrium global diperkirakan 3,9 g/hari (setara dengan $10 \mathrm{~g} / \mathrm{hari}$ garam) yang melebihi asupan maksimum yang disarankan yaitu $2 \mathrm{~g} /$ hari natrium atau setara dengan $5 \mathrm{~g} /$ hari garam [2]. Selama ini kebanyakan orang mengkonsumsi makanan hanya memikirkan selera dan rasanya saja sehingga kurang memperhatikan apa yang dibutuhkan oleh tubuh.

Unsur mineral merupakan salah satu komponen yang sangat diperlukan oleh tubuh di samping karbohidrat, protein, lemak dan vitamin [3]. Natrium merupakan unsur mineral makro yang sangat penting bagi kesehatan. Kebutuhan badan akan natrium klorida didasarkan pada konsumsi air. Disarankan 1 gram natrium klorida untuk setiap liter air yang diminum. Seorang dewasa diperkirakan memerlukan $1 \mathrm{~mL}$ air/kkal per hari. Orang yang mengkonsumsi 2.500-3.000 kkal memerlukan natrium klorida 2,5-3,0 g/hari [4]. Di dalam kenyataannya tingkat konsumsi garam masyarakat Indonesia jauh lebih tinggi dari angka tersebut. Tubuh membutuhkan natrium untuk membantu menjaga keseimbangan cairan tubuh, membantu mengirimkan impuls saraf dan proses kontraksi dan relaksasi otot. Namun demikian, mengkonsumsi natrium dengan kadar tinggi juga tidak disarankan karena dapat menyebabkan gangguan pada kesehatan seperti hipertensi [4]. Cara yang cukup efektif untuk mengatasi gangguan hipertensi salah satunya dengan mengoptimalkan bentuk fisik garam dapat dilakukan untuk mengurangi kandungan garam 
tanpa mengurangi kualitas yang dirasakan dalam makanan.

Kristal garam yang sebagian terlarut dalam mulut ditelan tanpa memberikan rasa asin. Untuk meningkatkan rasa asin dan menghindari garam tertelan sebelum terlarut dalam mulut maka tingkat kelarutan kristal garam harus ditingkatkan. Laju kelarutan kristal dapat ditingkatkan dengan memperbesar luas permukaan kristal yang kontak dengan pelarut. Hal ini dapat dicapai dengan membuat kristal garam yang berukuran kecil. Kristal garam dengan ukuran kecil dapat diperoleh dengan pemecahan kristal besar atau dengan metode rekristalisasi [5].

\section{EKSPERIMEN}

\section{Material}

Bahan-bahan yang digunakan dalam penelitian ini adalah akuades, garam dapur, kertas saring whatmann (no.41), aseton teknis, minyak zaitun ekstra virgin, minyak kelapa sawit dan lemak sapi.

\section{Instrumentasi}

Instrumen yang digunakan pada penelitian ini adalah $X$-Ray Diffraction (XRD) Philips PW 1835 dan Scanning Elektron Microscopy-Energy Dispersive X-Ray (SEM-EDX).

\section{Prosedur}

\section{Pembuatan larutan garam}

Sebanyak 130 g garam dimasukkan kedalam gelas kimia dan dilarutkan dalam akuades. Larutan dipindahkan ke dalam labu ukur $500 \mathrm{~mL}$ kemudian ditambahkan akuades hingga tanda batas dan dihomogenkan.

\section{Rekristalisasi}

Minyak nabati (minyak zaitun, minyak kelapa sawit) dan lemak hewani (minyak lemak sapi) dipanaskan pada bak penangas yang berisi pasir sampai suhu $181{ }^{\circ} \mathrm{C}$, diteteskan $80 \mathrm{~mL}$ larutan garam dengan menggunakan pipet tetes kedalam minyak pada rentang suhu $181-179{ }^{\circ} \mathrm{C}$, tetesan air garam didiamkan dalam minyak sampai air menguap dan terjadi pembentukan kristal $\mathrm{NaCl}$. Setelah proses rekristalisasi, minyak yang mengandung kristal garam didiamkan pada suhu ruang selama kurang lebih 24 jam sehingga garam bisa mengendap. Kemudian supernatan minyak dibuang dan ditambahkan aseton pada kristal garam dengan perbandingan $1: 10$ (bubur garam dan minyak : aseton). Campuran garam, minyak dan aseton kemudian diaduk menggunakan pengaduk magnet selama 10 menit dan disaring menggunakan saringan vakum. Kristal garam kemudian didiamkan dalam suhu ruang hingga beratnya konstan, lalu dikeringkan dalam oven selama 1 jam pada suhu $150{ }^{\circ} \mathrm{C}$, didinginkan dalam desikator dan ditimbang berat kristal yang diperoleh.

\section{Karakterisasi}

Kristal garam yang diperoleh di bawah kondisi yang berbeda dikarakterisasi dengan menggunakan difraksi sinar-X (XRD) dan Scanning Electron Microscopy (SEM).

\section{Uji Kadar Air}

Kadar air kristal garam ditentukan dengan metode termogravimetri. Cawan dipanaskan dalam oven selama 15 menit dan didinginkan dalam desikator kemudian ditimbang sampai diperoleh berat konstan. Sebanyak $2 \mathrm{~g}$ kristal garam ditempatkan pada cawan dan dipanaskan pada suhu $120{ }^{\circ} \mathrm{C}$ selama 1 jam kemudian didinginkan dalam desikator dan ditimbang, perlakuan ini diulangi sampai didapatkan berat konstan.

\section{HASIL DAN PEMBAHASAN}

\section{Pembuatan Larutan Garam}

Rekristalisasi garam untuk membuat garam dengan ukuran mikro (mikrokristal garam) dilakukan dari larutan garam 26\% dengan menggunakan minyak sebagai medium kristalisasinya. Untuk membuat larutan garam $26 \%$, garam ditimbang sebanyak $130 \mathrm{~g}$ kemudian dilarutkan dalam $500 \mathrm{~mL}$ akuades. Garam dapur $(\mathrm{NaCl})$ merupakan senyawa yang terikat dengan ikatan ionik. Garam $\mathrm{NaCl}$ ketika dilarutkan dalam air maka akan terbentuk interaksi ion-dipol antara $\mathrm{NaCl}$ dengan molekul air.

Molekul air memiliki sifat polar (dwikutub) dengan muatan positif lebih terpusat pada atom hidrogen dan muatan negatif pada atom oksigen. Dalam proses pelarutan $\mathrm{NaCl}$, kutub negatif oksigen dari molekul air akan mengepung dan menarik kation (natrium) dan kutub positif atom hidrogen akan mengepung dan menarik anion (klorida) seperti yang ditunjukan pada Gambar 1. [6]. 


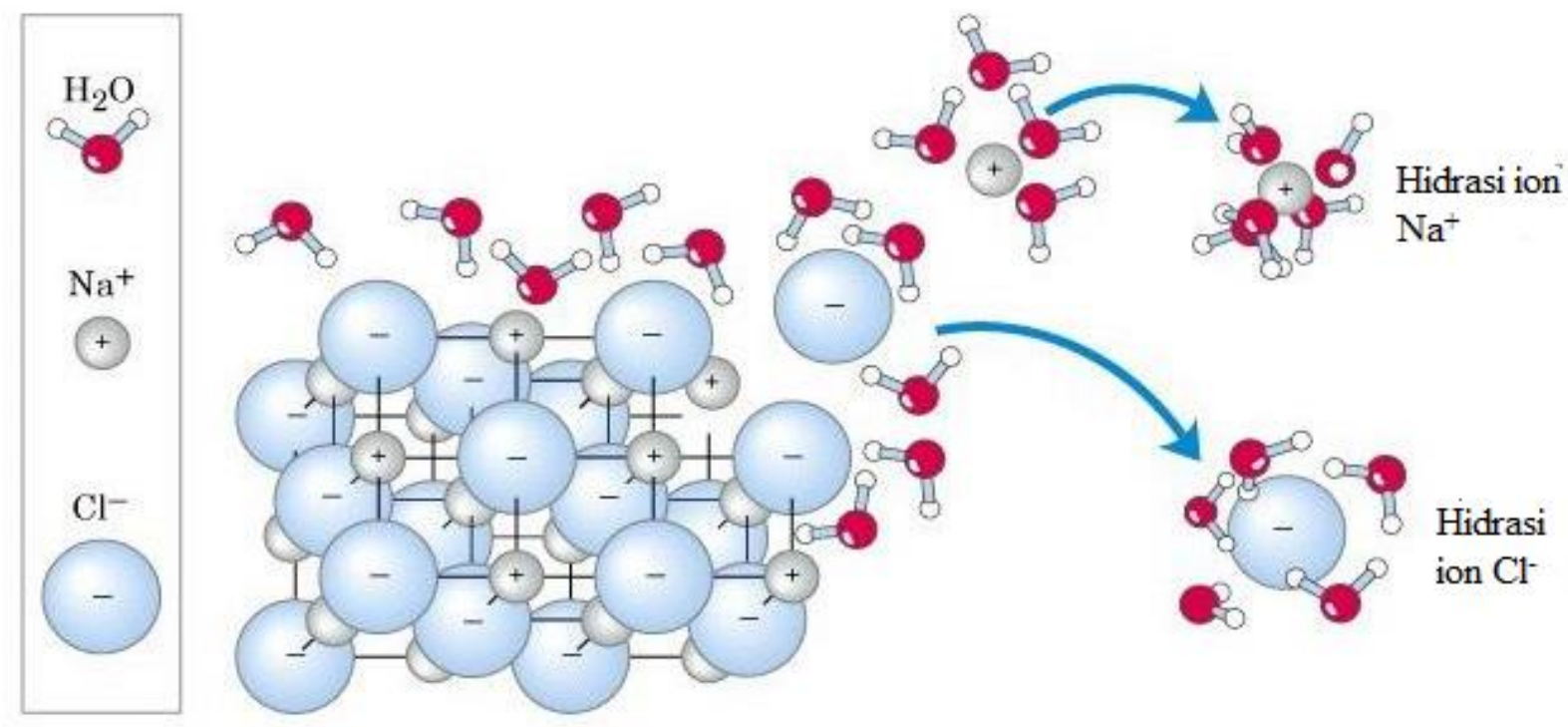

Gambar 1. Hidrasi Ion $\mathrm{NaCl}[6]$.

Proses pelarutan $\mathrm{NaCl}$ dalam air dapat dituliskan seperti pada persamaan (1).

$$
\mathrm{NaCl}_{(\mathrm{s})}+\mathrm{H}_{2} \mathrm{O}_{(\mathrm{aq})} \rightarrow \mathrm{Na}_{(\mathrm{aq})}^{+}+\mathrm{Cl}_{(\mathrm{aq})}^{-}
$$

\section{Rekristalisasi}

Larutan garam yang telah dibuat kemudian dibagi menjadi tiga perlakuan yaitu direkristalisasi dengan menggunakan minyak lemak sapi, minyak kelapa sawit dan minyak zaitun. Kristalisasi bisa terjadi dari fasa uap, pemadatan cairan pada titik lelehnya atau kristalisasi dari suatu larutan. Pada penelitian ini rekristalisasi garam dilakukan dari larutannya dengan penguapan pelarut (akuades) dengan menggunakan minyak sebagai medium rekristalisasinya. Minyak dipanaskan hingga mencapai suhu $181^{\circ} \mathrm{C}$ dengan menggunakan pasir sebagai penangas, pasir dipilih sebagai penangas karena memiliki titik leleh yang tinggi sehingga dapat mencapai suhu pemanasan minyak yang digunakan untuk medium rekristalisasi garam. Tujuan digunakannya penangas dalam memanaskan minyak adalah agar tidak terjadi perubahan suhu yang drastis pada minyak sehingga suhu minyak dapat dipertahankan agar tetap konstan. Setelah minyak mencapai suhu $181^{\circ} \mathrm{C}$ diteteskan larutan garam $26 \%$ sebanyak 80 $\mathrm{mL}$ tetes demi tetes kedalam minyak, penetesan larutan garam ini dilakukan pada rentang suhu minyak $179-181^{\circ} \mathrm{C}$. Larutan garam dimasukkan tetes demi tetes kedalam minyak panas karena pada saat ditetesi larutan garam, suhu minyak akan mengalami penurunan. Jika penambahan dilakukan dengan jumlah yang banyak secara langsung maka akan terjadi penurunan suhu yang cukup drastis pada minyak yang digunakan sebagai medium rekristalisasi. Ketika larutan garam diteteskan kedalam minyak panas maka air dari larutan garam akan menguap karena suhu minyak yang dipanaskan jauh lebih tinggi dari titik didih air yaitu $100^{\circ} \mathrm{C}$, sementara garam dari larutan akan mengalami rekristalisasi didalam minyak membentuk mikrokristal garam.

\section{Pemisahan Garam}

Setelah garam direkristalisasi dalam minyak kemudian bubur garam minyak ini didiamkan selama \pm 24 jam, tujuannya adalah agar kristal garam yang terbentuk mengendap pada dasar labu sehingga akan mudah dipisahkan dari minyak. Supernatan minyak kemudian dipisahkan dari kristal garam dengan cara didekantasi. Minyak yang menempel pada kristal garam kemudian dipisahkan dengan menggunakan aseton. Aseton ditambahkan kedalam campuran bubur garam dan minyak dengan perbandingan 1:10 (bubur garam minyak : aseton). Aseton dipilih sebagai pelarut karena minyak bersifat nonpolar dan dapat larut dalam aseton sehingga minyak yang tertinggal pada mikrokristal garam akan larut dalam aseton tetapi garam tidak akan larut.

Kristal garam yang telah dipisahakan dari minyak dimasukkan kedalam oven dan dipanaskan pada suhu $150^{\circ} \mathrm{C}$ Selama 1 jam, pemanasan ini dilakukan untuk menghilangkan air dan minyak yang tertinggal didalam kristal sehingga didapatkan kristal garam yang kering. 


\section{Kristalinitas}

Kristal yang telah dihasilkan kemudian dikarakterisasi dengan menggunakan instrument XRD untuk mengetahui kristalinitasnya. Lebar pada setengah puncak XRD dapat digunakan untuk mengukur keteraturan struktur kristal atau derajat kristalinitas dari suatu mineral. Luas puncak pada hasil karakterisasi menggunakan XRD sebanding dengan derajat kristalinitas, semakin besar luas puncak maka derajat kristalinitas kristal juga semakin tinggi. Ukuran partikel yang kecil dapat memperbesar pelebaran pada puncak difraksi dan menyebabkan luas puncak kristal menurun, Oleh karena itu, derajat kristalinitas akan menurun seiring dengan menurunnya ukuran kristal karena kristal dengan ukuran yang lebih besar memiliki keteraturan yang lebih tinggi daripada kristal berukuran kecil.

Dari hasil XRD diketahui kristalinitas pada kristal garam yang tidak direkristalisasi lebih besar jika dibandingkan dengan mikrokristal garam yang didapatkan dari hasil rekristalisasi, hal ini mengindikasikan bahwa kristalinitas dari garam sebelum mengalami rekristalisasi lebih baik dibandingkan dengan kristalinitas pada kristal garam hasil rekristalisasi. Peristiwa ini disebabkan karena garam hasil rekristalisasi memiliki ukuran yang lebih kecil sehingga terjadi pelebaran pada puncak difraksi dan menurunnya kristalinitas kristal.
Tabel 1. Sudut $2 \theta$ pada Difraktogram Mikrokrisrtal Garam

\begin{tabular}{ll}
\hline Mikrokristal Garam & \multicolumn{1}{c}{ Sudut 20 } \\
\hline Tanpa rekristalisasi & 27,$36 ; 31,70 ; 45,43 ;$ \\
& 56,$45 ; 66,36$. \\
Rekristalisasi dalam & 27,$34 ; 31,67 ; 45,54 ;$ \\
minyak lemak sapi & 56,$42 ; 66,34$. \\
Rekristalisasi dalam & 27,$49 ; 31,61 ; 45,57 ;$ \\
minyak zaitun & 56,$5 ; 66,33$. \\
Rekristalisasi dalam & 27,$35 ; 31,6 ; 45,57 ;$ \\
minyak kelapa sawit & 56,$44 ; 66,37$. \\
\hline
\end{tabular}

\section{Ukuran Kristal}

Ukuran kristal merupakan parameter yang penting untuk mengetahui material mikrokristal. Terdapat beberapa cara yang bisa digunakan untuk mengetahui ukuran kristal seperti menggunakan SEM dan XRD. Metode perhitungan ukuran kristalit dengan menggunakan hasil XRD lebih sederhana dan ukuran rata-rata kristal dapat dihitung dari informasi lebar setengah puncak yang dihasilkan dengan perhitungan menggunakan formula scherrer yang dapat menghubungkan antara lebar puncak difraksi dengan ukuran ratarata kristalit. Tetapi perhitungan ukuran kristal dengan menggunakan formula scherrer ini lebih tapat untuk mengukur kristal dengan ukuran nanopartikel. Selain menggunakan XRD, ukuran kristalit juga dapat ditentukan dengan menggunakan hasil karakterisasi SEM. Untuk gambar keseluruhan hasil SEM dapat dilihat pada Gambar 2.

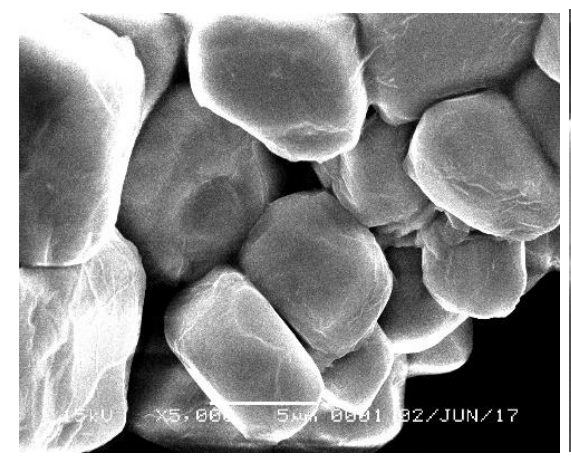

(a)

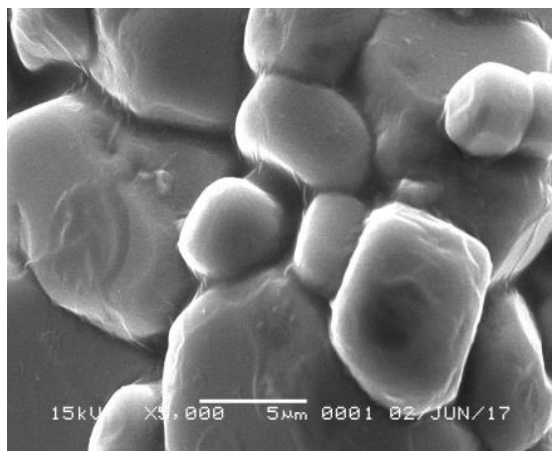

(b)

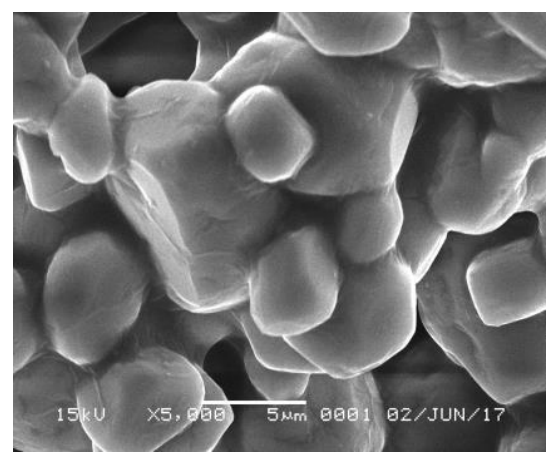

(c)

Gambar 2. (a) Hasil SEM Mikrokristal Garam dengan Medium Rekristalisasi Lemak Sapi; (b) Hasil SEM Mikrokristal Garam dengan Medium Rekristalisasi Minyak Kelapa Sawit; (c) Hasil SEM Mikrokristal Garam dengan Medium Rekristalisasi Minyak Zaitun.

Karakterisasi SEM pada mikrokristal garam dilakukan pada perbesaran 5000×, dari hasil karakterisasi SEM ini diketahui morfologi kristal garam berbentuk kubus dengan ukuran kristalnya dapat dilihat pada Tabel 2.
Ukuran kristal atau ukuran partikel ini selain berpengaruh pada nilai kristalinitas juga dapat mempengaruhi laju kelarutan kristal garam. Kelarutan merupakan batas maksimal suatu padatan yang dapat terkandung didalam suatu larutan. Ada beberapa hal yang dapat 
mempengaruhi kelarutan suatu padatan didalam pelarutnya, diantaranya yaitu: temperatur, luas permukaan dan pengadukan. Dalam kaitannya dengan ukuran partikel, maka ukuran partikel akan mempengaruhi luas permukaan suatu kristal. Karena ukuran kristal yang kecil, mikrokristal garam memiliki perbandingan nilai volume dan luas permukaan yang lebih besar jika dibandingkan dengan kristal garam dalam ukuran besar. Hal ini menjadikan mikrokristal garam lebih cepat larut dibandingkan kristal dengan ukuran yang besar pada jumlah yang sama. Kelarutan dipengaruhi oleh luas permukaan dari suatu partikel karena hanya partikel permukaan yang bersentuhan langsung dengan pelarut. Oleh karena itu, semakin besar luas permukaan kristal yang bersentuhan dengan pelarut maka laju kelarutan kristal akan lebih cepat.

Tabel 2. Ukuran Kristal dari Hasil Analisis XRD dan SEM

\begin{tabular}{lcc}
\hline \multirow{2}{*}{ Mikrokristal Garam } & \multicolumn{2}{c}{ Ukuran Kristal } \\
\cline { 2 - 3 } & XRD & SEM \\
\hline Rekristalisasi dalam & $51,33 \times 10^{-3}$ & $3,25-7,50$ \\
minyak sapi & $\mu \mathrm{m}$ & $\mu \mathrm{m}$ \\
Rekristalisasi dalam & $69,30 \times 10^{-3}$ & $2,00-7,50$ \\
minyak zaitun & $\mu \mathrm{m}$ & $\mu \mathrm{m}$ \\
Rekristalisasi dalam & $69,30 \times 10^{-3}$ & $2,50-5,25$ \\
minyak kelapa sawit & $\mu \mathrm{m}$ & $\mu \mathrm{m}$ \\
\hline
\end{tabular}

\section{Kadar Air}

Kadar air yang didapatkan dari mikrokristal garam dengan medium rekristalisasi minyak zaitun, minyak kelapa sawit, dan lemak sapi disajikan pada Tabel 3.

Tabel 3. Kadar Air Mikrokristal Garam

\begin{tabular}{lc}
\hline \multicolumn{1}{c}{ Medium Kristalisasi } & Kadar Air \\
\hline Minyak lemak sapi & $0,7 \%$ \\
Minyak sawit & $2,4 \%$ \\
Minyak zaitun & $1,1 \%$ \\
\hline
\end{tabular}

Pengukuran kadar air mikrokristal garam dilakukan dengan metode termogravimetri. Kadar air penting untuk diukur untuk menentukan umur simpan suatu bahan pangan. Kandungan air yang tinggi akan mengakibatkan bakteri mudah berkembang biak dan menyebabkan perubahan pada bahan pangan.

\section{SIMPULAN}

Dari hasil penelitian ini dapat ditarik kesimpulan sebagai berikut:
1. Mikrokristal garam dapat diperoleh dengan rekristalisasi menggunakan minyak hewani dan minyak nabati sebagai medium rekristalisasinya, tetapi didapatkan hasil yang berbeda baik dari segi ukuran maupun secara organoleptik.

2. Dari hasil karakterisasi SEM didapatkan ukuran kristal yang diperoleh dari hasil rekristalisasi menggunakan minyak lemak sapi, minyak zaitun dan minyak kelapa sawit berturut-turut adalah $3,25-7,50 \mu \mathrm{m}, 2-7,50$ $\mu \mathrm{m}$ dan $2,50-5,25 \mu \mathrm{m}$.

3. Kadar air dari mikrokristal garam yang diperoleh dari hasil rekristalisasi menggunakan minyak lemak sapi, minyak zaitun dan minyak kelapa sawit berturut-turut adalah $0,7 \%, 2,4 \%$ dan $1,1 \%$.

\section{UCAPAN TERIMA KASIH}

Penulis mengucapkan terima kasih kepada Laboratorium Pusat Survei Geologi (PSG) atas diskusi SEM dan Pusat Penelitian Bahan Tambang Teknik Mineral Batubara (PUSLITBANG TekMIRA) atas diskusi metode XRD.

\section{REFERENSI}

[1] F. J. He, "Reducing salt intake to prevent hypertension and cardiovascular disease," Revista Panamericana de Salud Pública, vol. 32(4), pp. 293 -300, 2012.

[2] S.Fahimi, R.Micha, S.Khatibzadeh, P.Shi, M.Ezzati,. D. Mozaffarian J.Powles, "Global, regional and national sodium intakes in 1990 and 2010: a systematic analysis of $24 \mathrm{~h}$ urinary sodium excretion and dietary surveys worldwide," British Medical Journal Open, vol. 3, 2013.

[3] Anna Poedjiadi and F.M Titin Supriyanti, Dasar-Dasar Biokimia. Jakarta: UI-Press, 2015.

[4] F.G. Winarno, Kimia Pangan dan Gizi. Jakarta: PT Gramedia Pustaka Utama, 1991.

[5] M., Astete, C., Sabliov, C., Olson, D., Boeneke, C., \& Aryana, K. J. Moncada, "Nano spray-dried sodium chloride and its effects on the microbiological and sensory characteristics of surface-salted cheese crackers.," Journal of Dairy Science, vol. 98, pp. 5946 -5954., 2015.

[6] Marcela Quilaqueo and José Miguel Aguilera, "Cristallization of $\mathrm{NaCl}$ by Fast Evaporation of Water in Droplets of $\mathrm{NaCl}$ Solution," Food Research International, vol. 84, 2016. 